\title{
Hepatoprotective and Antifibrotic Effects of Indonesian Propolis
}

\author{
Diding Heri Prasetyo, ${ }^{1}$ Sarsono, ${ }^{2}$ Ida Nurwati, ${ }^{2}$ R. Prihandjojo Andri Putranto, ${ }^{2}$ Martini, ${ }^{2}$ \\ Nabila Aushaf Prasetyo ${ }^{3}$ \\ ${ }^{1}$ Department of Internal Medicine, Faculty of Medicine, Universitas Sebelas Maret/Dr. Moewardi Hospital \\ Surakarta, Indonesia, ${ }^{2}$ Biochemistry Laboratory, Faculty of Medicine Universitas Sebelas Maret, Surakarta, \\ Indonesia, ${ }^{3}$ Faculty of Medicine Universitas Sebelas Maret, Surakarta, Indonesia
}

\begin{abstract}
Liver cirrhosis is the irreversible stage in liver damage process which occurs after liver fibrosis due to necroinflammatory activities and liver fibrosis. Therefore, inhibition of liver inflammation and fibrosis is very important to prevent liver cirrhosis. This study aimed to analyze the effect of ethanol extract of propolis (EEP) from mount Lawu, Indonesia to prevent liver damage and fibrosis progression in mice with hepatic cirrhosis. This study was performed during the period of June 2018 to May 2019 on a sample of 32 male Balb/C mice divided into control group (P1), induction of carbon tetrachloride $\left(\mathrm{CCl}_{4}\right)$ group (P2), induction of $50 \mathrm{mg} / \mathrm{BW} \mathrm{CCl}+\mathrm{EEP}_{4}$ group (P3), and (induction of $100 \mathrm{mg} / \mathrm{KgBW} \mathrm{CCl}_{4}+\mathrm{EEP}(\mathrm{P} 4)$ with each group consisted of eight mice. The $\mathrm{CCl}_{4}$ in olive oil was administered intraperitoneally three times a week for six weeks. Mean differences between group was determined using ANOVA test with a significance level of 0.05 . The induction of $\mathrm{CCl}_{4}$ increased liver cell damage and serum alanin aminotransferase (ALT) level. However, the addition of EEP significantly $(\mathrm{p}<0.001)$ reduced liver cell damage as seen in P3 (54.38 \pm 4.17 per 100 liver cells) and P4 (37.13 \pm 4.36 per 100 liver cells) groups and serum alanin aminotransferase (ALT) as seen in P3 (291.19 $\pm 113.92 \mathrm{U} / \mathrm{L})$ and P4 (229.38 $\pm 73.45 \mathrm{U} / \mathrm{L})$ groups. The APRI scores were also reduced after EEP as seen in P3 (0.738 \pm 0.292$)$ and P4 $(0.513 \pm 0.253)$ groups. Thus, EEP isolates from Gunung Lawu can reduce liver cell damage and fibrosis in mice model of hepatic cirrhosis.
\end{abstract}

Key words: ALT, APRI score, liver cirrhosis, liver damage, propolis

\section{Efek Hepatoprotektif dan Antifibrotik Propolis Indonesia}

\begin{abstract}
Abstrak
Sirosis hati (SH) merupakan tahap ireversibel dalam proses kerusakan hati yang terjadi setelah fibrosis hati sebagai hasil aktivitas nekroinflamasi dan fibrosis hati. Oleh karena itu, penghambatan inflamasi hati dan fibrosis sangat penting untuk mencegah terjadi SH. Penelitian ini bertujuan menganalisis efek ekstrak etanol isolat propolis (EEP) gunung Lawu dalam mencegah progresifitas kerusakan dan fibrosis hati pada mencit model SH. Penelitian dilakukan di Laboratorium Histolgis Fakultas Kedokteran Universitas Sebelas Maret Surakarta dan Lembaga Penelitian dan Pengujian Terpadu (LPPT) Universitas Gajah Mada Yogyakarta. Penilitian ini dilakukan periode Juni 2018 sampai Mei 2019, dengan sampel 32 ekor mencit Balb/C jantan dibagi menjadi kelompok (P1) kontrol negatif, (P2) induksi karbon tetraklorida $\left(\mathrm{CCl}_{4}\right)$, (P3) induksi $\mathrm{CCl}_{4}+\mathrm{EEP}$ dosis 50 mg.kgBB-1, dan (P4) induksi $\mathrm{CCl}_{4}+\mathrm{EEP}$ dosis $100 \mathrm{mg} \cdot \mathrm{kgBB}-1$, dengan tiap-tiap sampel terdiri atas delapan ekor mencit Balb/C jantan. $\mathrm{CCl}_{4}$ dalam minyak zaitun diberikan pada tikus Balb/C tiga kali seminggu selama enam minggu secara intraperitoneal. Uji ANOVA digunakan untuk menentukan perbedaan rerata antarkelompok dengan tingkat kemaknaan sebesar 0,05. Namun, penambahan EEP secara signifikan $(\mathrm{p}<0,001)$ menurunkan tingkat kerusakan sel hati seperti yang terlihat pada P3 (54,38 $\pm 4,17$ per 100 sel hati) dan kelompok P4 (37,13 $\pm 4,36$ per 100 sel hati) dan serum alanin aminotransferase (ALT) seperti yang terlihat dalam kelompok P3 $(291,19 \pm 113,92$ U/L) dan P4 $(229,38 \pm 73,45 \mathrm{U} / \mathrm{L})$. Hasil skor APRI menunjukkan kelompok P1 $(0,213 \pm 0,113)$ dan P2 $(0,863 \pm 0,534)$, EEP dapat menurunkan skor APRI pada kelompok P3 $(0,738 \pm 0,292)$ dan P4 $(0,513 \pm 0,253)$. Simpulan, EEP isolat Gunung Lawu menurunkan tingkat kerusakan sel hati dan fibrosis pada mencit model SH.
\end{abstract}

Kata kunci: Kerusakan hepar, propolis, SGPT, sirosis hepatis, skor APRI

Corresponding Author: Diding Heri Prasetyo, Department of Internal Medicine, School of Medicine, Universitas Sebelas Maret/Dr. Moewardi Hospital Surakarta, Jalan Kolonel Sutarto No. 132, Jebres, Surakarta, Central Java, Indonesia, Email: didinghapeuns@gmail.com 


\section{Introduction}

Liver cirrhosis, a final pathway of various chronic liver diseases, is a pathologic entity defined as diffuse hepatic fibrosis with normal liver architecture replacement by nodules. ${ }^{1}$ Liver fibrosis is attributed to inflammation, excessive accumulation of extracellular matrix (ECM), and tissue remodeling under wound healing., ${ }^{2,3}$ Chronic hepatitis and liver cirrhosis are positively associated with the occurrence of hepatocellular carcinoma; therefore, the inhibition of hepatic inflammation and fibrosis is crucial to prevent liver cirrhosis and hepatocellular carcinoma.

The Aspartate Aminotransferase Platelet Ratio Index (APRI) score is a simple non-invasive diagnostic tool for predicting liver fibrosis and cirrhosis. ${ }^{4}$ Hence, this score can be used to compare the possibility of progressing into liver fibrosis and cirrhosis in different groups of patients.

Hepatotoxicity of carbon tetrachloride $\left(\mathrm{CCl}_{4}\right)$ involves its biotransformation into free radicals such as trichloromethyl free radical $\left(\mathrm{CCl}_{3}\right)$ and trichloroperoxyl radical, which may increase lipid peroxidation., ${ }^{3,4}$

Propolis as a natural product derived from plant resins collected by honey bees has a number of biological activities, such as anti-inflammatory and antioxidant activities. Antioxidant activities of propolis are especially due to its flavonoid content (caffeic acid phenethyl ester/CAPE). ${ }^{5}$ CAPE can also inhibit the nuclear factor NF- $\kappa B$ pathway. ${ }^{6}$ Biological, geographical, and environmental zone factors can affect the amount and quality of propolis production. ${ }^{7}$ Identification of the main active ingredient in the ethanol extract of Mount Lawu propolis isolates had been able to identify the CAPE content of $30.24 \pm 3.53 \times 10^{-6}$ grams and quercetin content of $4.42 \pm 0.50 \times 10^{-6}$ grams. $^{8}$ This information is used to determine the propolis dose. A study has shown that, as an anti-inflammatory agent, the ethanol extract from Mount Lawu propolis isolates decreases the High-Mobility Group Box 1 (HMGB-1) in mice model of male infertility whereas as an antioxidant, the dose of $100 \mathrm{mg} \cdot \mathrm{kgBW}^{-1}$. day ${ }^{-1}$ for 30 days reduces the malondialdehyde (MDA) level as one of the biomarkers of oxidative stress and increases superoxide dismutase (SOD) as one of the main intracellular antioxidant defense mechanisms. ${ }^{9,10,11}$ Propolis is expected to have the effect of inhibiting the progression of liver fibrosis into liver cirrhosis.

The purpose of this study was to analyze the effect of ethanol extract of propolis (EEP) from mount Lawu isolates in preventing liver damage and fibrosis progression in mice model with liver cirrhosis.

\section{Methods}

This was a laboratory experimental study conducted at the Histology Laboratory of the Faculty of Medicine, Sebelas Maret University, Surakarta, Indonesia and the Integrated Research and Testing Institute of Gajah Mada University, Yogyakarta, Indonesia. This study was conducted in the period of June 2018 to May 2019 on a total of 32Balb/C mice weighing 15-20 g and aged 4-6 weeks which were purchased from the Laboratory Animal House of Setya Budi University, Surakarta. The mice were kept for 2 weeks to be acclimatized before the commencement of the experiment. All mice were kept in a cage with saw dust covered floor that was placed in a quiet and temperaturecontrolled room $\left(23 \pm 4^{\circ} \mathrm{C}\right)$. Standard diet was provided ad libitum. All protocols regarding this study have been approved by the the health research ethics committee through the issuance of the ethical clearance number 96/UN27.6/ KEPK/2018. The experiment was conducted according to the ethical guidelines for the use of animals in laboratory experiments of the Faculty of Medicine, Sebelas Maret University, Surakarta. Mice were randomly divided into 4 experimental groups with 8 mice per group: a control group consisting mice fed with standard diet (P1), mice treated with $\mathrm{CCl}_{4}(2 \mathrm{~mL} / \mathrm{kgBW}$, of $2: 5 \mathrm{v} / \mathrm{v}$ in olive oil, intraperitonially) three times a week for six weeks (P2), (mice treated with daily dose of $\mathrm{CCl}_{4}+\mathrm{EEP}\left(50 \mathrm{mg} \cdot \mathrm{kgBW}^{-1}\right)$ via gastric tube (P3) and mice treated with daily dose of $\mathrm{CCl}_{4}+\mathrm{EEP}$ $\left(100\right.$ mg.kgBW $\left.{ }^{-1}\right)$ via gastric tube (P4)y. ${ }^{12,13}$

On the $42^{\text {nd }}$ day, the mice were sacrificed. Liver tissue was removed and histopathological preparations were made according to the standard method of the Histology Laboratory of the Faculty of Medicine, Sebelas Maret University, Surakarta, for histopathological examinations (liver fibrosis). Serum collection for serum alanin aminotransferase (ALT) examination, serum aspartate aminotransferase (AST), and platelets was performed to determine the degree of liver damage and fibrosis using the APRI scores.

APRI score is a simple diagnostic tool for predicting fibrosis and cirrhosis. ${ }^{4}$ APRI score measurement uses an APRI calculator tool with the following formula: 
APRI $=\frac{((\text { AST level }(\mathrm{IU} / \mathrm{L}))}{\frac{(\text { AST }(\text { Upper Limit of Normal })(\mathrm{IU} / \mathrm{L})))}{\left(\text { Platelet count }\left(10^{9} / \mathrm{L}\right)\right)}} \times 100$

The bee propolis in this study was obtained from beekeepers in Kerjo, Karanganyar, Surakarta, Central Java, Indonesia. Extraction was carried out using the percolation method with $80 \%$ ethanol extraction liquid. Approximately $1 \mathrm{~g}$ (weighing accuracy of up to $0.0001 \mathrm{~g}$ ) raw propolis powder was extracted with $10 \mathrm{~mL}$ of $80 \%$ ethanol in a shaker at a speed of $200 \mathrm{rpm}$ at room temperature for 24 hours. After filtering using a filter paper, filtrate was gained up to 25 $\mathrm{mL}$ with $80 \%$ ethanol. This filtrate was stored in bottles until analysis.

Data obtained were analyzed using the SPSS for Windows Release 15 program and $\mathrm{p}<0.05$ was chosen as the minimum level of significance. ANOVA test or alternative was used for data analysis.

\section{Results}

Results showed that, at the cellular level, the level of liver cell damage in the control mice group was $30.25 \pm 4.62$ per 100 liver cells. $\mathrm{CCl}_{4}$ induction significantly increased liver cell damage to $75.00 \pm 5.93$ per 100 liver cells $(p<0.001)$. This evidence of liver cell damage was strengthened by the results of biochemical examination showing the increase of ALT level from $71.25 \pm 18.14 \mathrm{U} / \mathrm{L}$ in the control group into $305.25 \pm 121.44 \mathrm{U} / \mathrm{L}(\mathrm{p}<0.001)$ in the $\mathrm{CCl}_{4}$ induced group. Provision of EEP was able to significantly reduce liver cell damage $(\mathrm{p}<0.001)$, both cellularly and biochemically, which was apparent from the results in the P3 group with an EEP dose of $50 \mathrm{mg} / \mathrm{kgBW} /$ day/orally and P4 group with a dose of $100 \mathrm{mg} / \mathrm{kgBW} /$ day/orally of 54.38 \pm 4.17 per 100 cells liver and ALT levels $291.19 \pm 113.92 \mathrm{U} / \mathrm{L}$ in P3 and 37.13 \pm 4.36 per 100 liver cells and ALT levels 229.38 $\pm 73.45 \mathrm{U} / \mathrm{L}$ in P4. The difference in the average rate of liver cell damage between sample groups is depicted below (Figure 1).

Based on the variable description of ALT and AST levels, it was revealed that $\mathrm{CCl}_{4}$ induction increased the mean liver cell damage when compared to the control group. Providing EEP to mice that have been induced by $\mathrm{CCl}_{4}$ can reduce the average liver cell damage. The differences in average liver cell damage based on ALT and AST levels between groups of samples are described below (Figure 2 and 3 ).

Results of the meta-analysis concluded that the APRI score greater than 1.0 has a sensitivity of $76 \%$ and a specificity of $72 \%$ to predict cirrhosis. In addition, the APRI score greater than 0.7 has a sensitivity of $77 \%$ and a specificity of $72 \%$ to predict liver fibrosis. ${ }^{14}$ The results of the antifibrosis analysis in this study showed that the average APRI score of the control

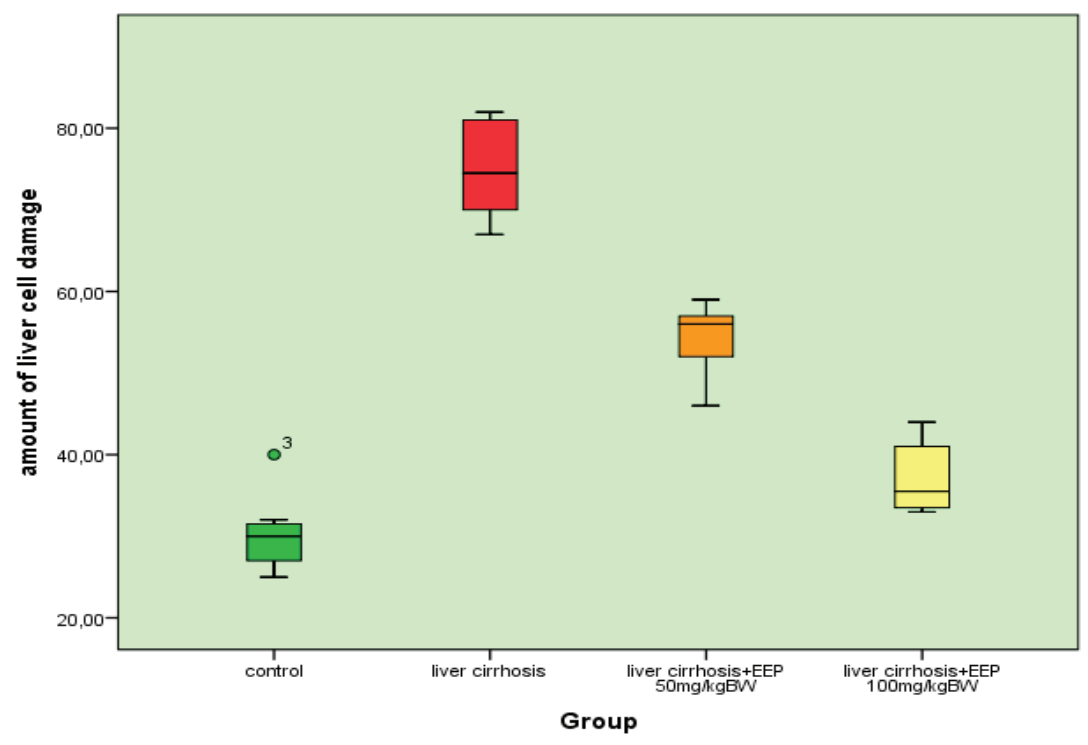

Figure 1 Comparison of the Average Number of Liver Cell Damage (per 100 Liver Cells) between Sample Groups $(* * p<0.01)$ 


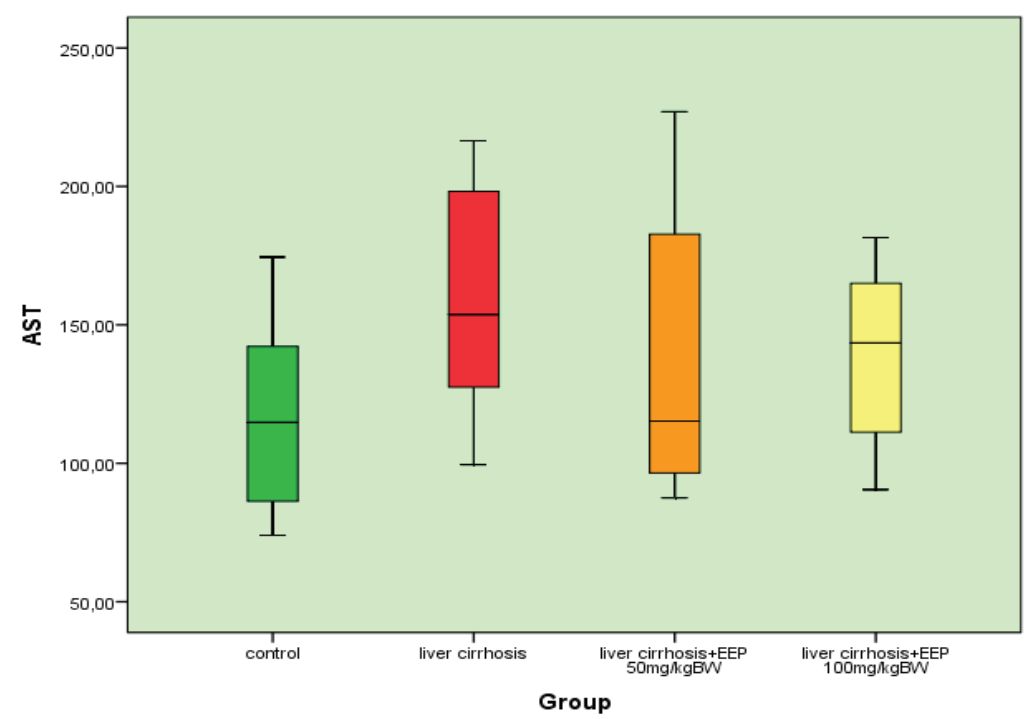

Figure 2 Comparison of ALT Levels between Sample Groups (ns: Non-Significant)

group was $0.213 \pm 0.113$. Induction of $\mathrm{CCl}_{4}$ $(\mathrm{p}=0.042)$ increased the average APRI score to $0.863 \pm 0.534$. The administration of EEP therapy at a dose of $50 \mathrm{mg} / \mathrm{kgBW} /$ day (P3) and $100 \mathrm{mg} /$ $\mathrm{kgBW} /$ day (P4) reduced the average APRI score to $0.738 \pm 0.292(\mathrm{p}=0.936)$ and $\mathrm{E} 0.513 \pm 0.253$ $(p=0.385)$, respectively, when compared to the liver cirrhosis group (P2). These results indicate that the level of liver fibrosis or cirrhosis can be suppressed by EEP, albeit insignificantly. This is probably because fibrosis is a reversible process. This study showed used the following
APRI score definition: normal (APRI <0.5), fibrosis (APRI 0.5 to <1.0), and cirrhosis (APRI $>1.0$ ). The formation of liver fibrosis was seen in $25 \%$ of mice with $50 \%$ of them took the form of liver cirrhosis after 42 days. The provision of EEP with a dose of $50 \mathrm{mg} / \mathrm{kgBW} /$ day was able to reduce the degree of liver cirrhosis, which emphasizes the correlation between the degree of liver cirrhosis and increasing EEP dose. The differences in the degree of liver cirrhosis based on APRI scores between groups are described as follows (Figure 4).

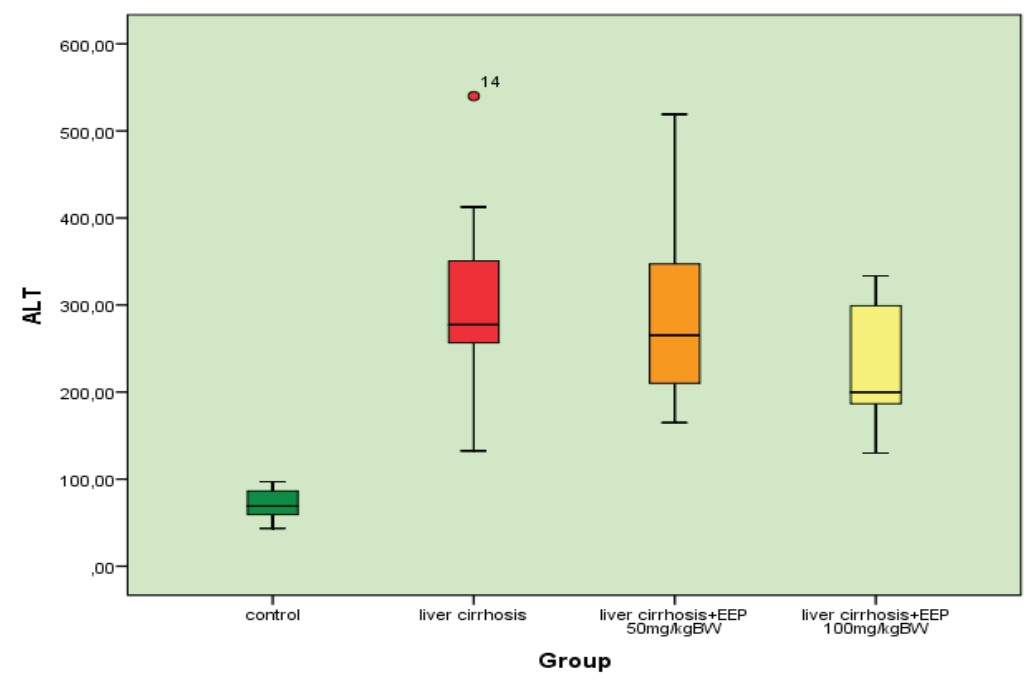

Figure 3 Comparison of AST Levels Between Sample Groups (ns: Non-Significant) 


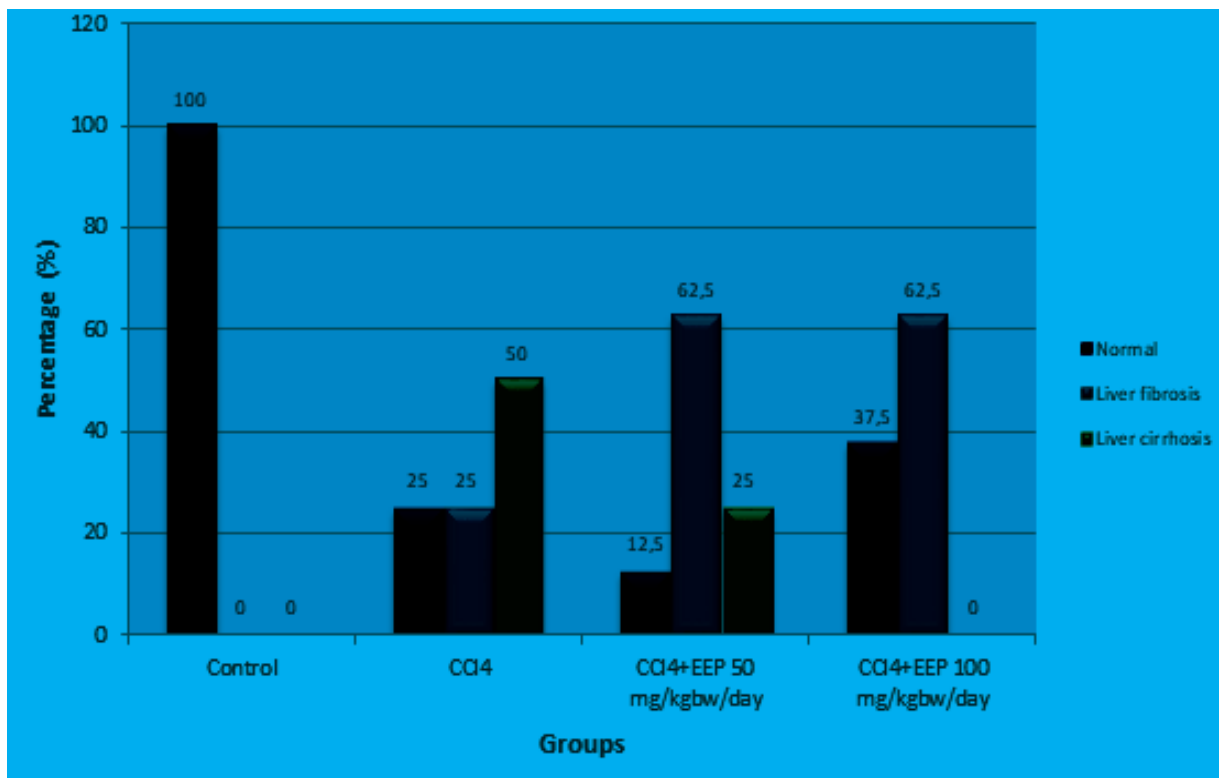

Figure 4 Comparison of Liver Cirrhosis Degree by APRI Scores between Sample Groups

\section{Discussion}

Many studies have used $\mathrm{CCl}_{4}$ to induce liver cirrhosis in experimental animal. The liver damage due to the administration of $\mathrm{CCl}_{4}$ starts with its binding to the hepatocyte cell membrane receptor which then stimulates the NADPH enzyme located in the mitochondria to form reactive oxygen species (ROS). This process is similar to the initial stage (incubation period/ sub-clinical) of the disease process. The liver tissue damage in this study can be detected at both biochemical and cellular levels. At the biochemical level, the detection was done through changes in serum alanine transaminase (ALT/AST) levels that was measured using the enzymatic photometric methods as well as through the capillary thrombocyte level as the indicator of liver injury. At the cellular level, the damage was detected histologically.

Carbon tetrachloride as a hepatotoxic material is destructive to liver cells. The administration of CCl4 causes a multifactor effect on the liver, including its toxic effects triggered by reactive metabolites, ROS, inflammatory reactions, and imbalances between cellular damage and protection responses which ultimately result in inflammation, oxidative stress induction and fibrosis in the liver. ${ }^{15,16} \mathrm{~A}$ single dose of $\mathrm{CCl}_{4}$ causes centrizonal necrosis and steatosis while prolonged administration will lead to liver fibrosis, cirrhosis, and hepatocellular carcinoma. $\mathrm{CCl}_{4}$ directly damages hepatocytes by changing plasma, lysosomal, and mitochondrial membrane permeabilities. Highly reactive free radical metabolism is also formed by the oxidation system in hepatocytes via CYP2E1, causing severe centrilobular necrosis. ${ }^{17}$

Carbon tetrachloride is one of the xenobiotics that has been reported to induce acute and chronic tissue injuries through bioactivation of the phase I cytochrome P450 system to form reactive metabolic trichloromethyl radicals $\left(\cdot \mathrm{CCl}_{3}\right)$ and peroxy trichloromethyl radicals $\left(\cdot 00 \mathrm{CCl}_{3}\right)$. These free radicals can covalently bind to macromolecules such as proteins, lipids, and nucleic acids. The double allylic hydrogen bonds of polyunsaturated fatty acid (PUFA) are susceptible to abstraction by free radicals; $\mathrm{CCl}_{4}$ exposure induces an increase in lipoperoxide and free peroxide radical concentrations that are highly reactive and cause injury or necrosis. ${ }^{2,3,18}$

Based on the epistomology approach principles that refer to previous findings, this study showed that the long-term administration of $\mathrm{CCl}_{4}$ i.e. 42 days, caused liver damage which begins with the necrosis of liver cells. In the liver cirrhosis group, there was a significant increase in liver damage which was evident from increased number of liver cells that experienced pycnosis, karyorrhexis, and karyolysis. The administration of $\mathrm{CCl}_{4}$ triggers liver necrosis due to lipid peroxidase and free radicals which eventually leads to hydropic degeneration, 
separate cell structures, and pycnotic cell nuclei (karyopyknosis), namely cell nucleus shrinkage and chromatin condensation. The cell then undergoes karyorrhexis and karyolysis. This study showed normal conditions of liver cells with pycnosis $(18.3 \pm 2.8 \%)$, karyorrhexis $(8.5 \pm 2.9 \%)$ and karyolysis $(3.5 \pm 1.4 \%)$. The administration of $\mathrm{CCl}_{4}$ increased the process of necrosis that liver cells experienced pycnosis $(47.4 \pm 6.4 \%)$, karyorrhexis $(14.3 \pm 3.9 \%)$, and karyolysis (14.6 $\pm 4.2 \%)$. The administration of EEP was able to reduce the rate of liver cell damage based on the finding that the EEP dose of $100 \mathrm{mg} / \mathrm{kgbw} /$ day can reduce the necrosis process by decreasing pycnosis $(15.9 \pm 2.5 \%)$, karyorrhexis $(12.4 \pm 2.4 \%)$, and karyolysis $(8.9 \pm 1.9 \%)$.

Cellular results were strengthened by biochemical results, namely significant increase in ALT levels after he administration of $\mathrm{CCL}_{4}$. Likewise, the provision of EEP can reduce the increase in ALT levels. The occurrence of necrosis causes liver cell to undergo karyolysis that will trigger the formation of pathogen-associated molecular patterns (PAMPs). These PAMPs will then activate the immune response through oxidative stress pathways, growth factors, and inflammation. In the end, this will stimulate the liver cells to become active, thus triggering the liver fibrogenesis process or final stage of liver cirrhosis. In this study, the process of fibrogenesis or liver cirrhosis was seen indirectly through the measurement of APRI scores as a non-invasive predictor of fibrogenesis or liver cirrhosis. The provision of $\mathrm{CCL}_{4}$ significantly increased APRI scores, meaning that it accelerates the process of fibrogenesis and liver cirrhosis which is in line with the research of Khan et al. ${ }^{18}$ that induction using CCL increases ALT and liver cell DNA fragmentation. ${ }^{4}$ Meanwhile, the administration of EEP was able to reduce the APRI score or suppress the occurrence of fibrogenesis and liver cirrhosis processes. This reduction was in parallel with the increase dose of EEP. An EEP dose of $100 \mathrm{mg} / \mathrm{kgBW} /$ day was able to inhibit liver cell damage and the process of fibrogenesis and liver cirrhosis in a significant way. Unfortunately, no APRI score reference is available for experimental animals.

The induction of $\mathrm{CCl}_{4}$ in mice increases liver cell thickness, which is apparent from the increase in ALT and AST levels and the level of liver cell thickness. The $\mathrm{CCl}_{4}$ causes acute hepatocyte injury, alters membrane integrity and, as a result, leakage of hepatocyte enzyme. After the administration of EEP, the pathological increase in ALT, AST and liver cell level can significantly be prevented. This indicates that EEP has the ability to protect against $\mathrm{CCl}_{4}^{-}$ induced hepatocyte (hepatoprotective) injury as also mentioned in previous studies that reported the protective effect of $\mathrm{CCl}_{4}$-induced polyphenol compounds on liver cirrhosis. ${ }^{18}$ The same result was also reported by Susanto et al. ${ }^{10,11}$ stating that the administration of Gunung Lawu propolis isolate with a dose of $100 \mathrm{mg} / \mathrm{kgBW} /$ day, reduced malondialdehyde (MDA) as one of the oxidative stress biomarkersand increased superoxide dismutase (SOD) as one of the main mechanisms of intracellular antioxidant defense. ${ }^{10,11}$

Based on the axiological principle, the overall benefit of the results of this study is that EEP can prevent or reduce the hepatotoxic effects, including fibrogenesis and liver cirrhosis. EEP can reduce the occurrence of liver cirrhosis through the mechanism of biological activities such as anti-inflammatory and antioxidants. Antioxidant activities of propolis, especially the CAPE content, has a hepatoprotective nature due to its biological activities such as cytoprotective, anti-oxidant, anti-proliferative, and anti-inflammatory properties which have been shown to inhibit lipoxygenase activity and lipid peroxidation. ${ }^{5,19}$ CAPE can also inhibit the $\mathrm{NF}-\mathrm{KB}$ transcription factor.

In conclusion, the administration of Mount Lawu propolis isolates from Indonesia can significantly reduce the level of liver cell damage, both cellularly and biochemically, and reduce the APRI score in the liver cirrhosis mice model. This indicates that Indonesian propolis isolates have hepatoprotector and antifibrosis properties in liver cirrhosis. Therefore, it is possible to use theIndonesian propolis isolates as an adjuvant therapy to inhibit the development of liver cirrhosis disease. However, further research is needed to measure the degree of fibrosis molecularly or cellularly.

\section{References}

1. Kamath PS, Shah VH. Overview of Cirrhosis. In: Feldman $\mathrm{M}$, Friedman LS Brandt LJ, editors. Sleisenger and Fordtran's gastrointestinal and liver disease. $10^{\text {th }} \mathrm{ed}$. Philadelphia: Saunders Inc; 2016. p. 125460.

2. Islam $\mathrm{A}, \mathrm{Al}$ Mamun $\mathrm{A}$, Faruk Ul Islam $\mathrm{T}$, Rahman M, Alam MN, et al. Astaxanthin ameliorates hepatic damage and oxidative stress in carbon tetrachloride-administered 
rats. Pharmacognosy Res. 2017;9(Suppl 1): S84-91.

3. Aydin MM, Akcali KC. Liver fibrosis. Turk J Gastroenterol. 2018;29(1):14-21.

4. Jain P, Tripathi BK, Gupta B, Bhandari B, Jalan D. Evaluation of aspartate aminotransferaseto-platelet ratio index as a non-invasive marker for liver cirrhosis. J Clin Diagn Res. 2015;9(11):0C22-4.

5. Tolba MF, Omar HA, Azab SS, Khalifa AE, Abdel-Naim AB, Abdel-Rahman SZ. Caffeic acid phenethyl ester: a Review of its antioxidant activity, protective effects against ischemia-reperfusion injury and drug adverse reactions. Crit Rev Food Sci Nutr. 2016; 56(13):2183-90.

6. Bezerra RM, Veiga LF, Caetano AC, Rosalen PL, Amaral ME, Palanch AC, et al. Caffeic acid phenethyl ester reduces the activation of the nuclear factor $\kappa \mathrm{B}$ pathway by high-fat dietinduced obesity in mice. Metabolism. 2012; 61(11):1606-14.

7. Bankova V, Popova M, Trusheva B. Propolis volatile compounds: chemical diversity and biological activity: a review. Chem Cent J. 2014;8:28.

8. Sarsono, Syarifah I, Martini, Diding HP. Identifikasi caffeic acid phenethyl ester dalam ekstrak etanol propolis isolat gunung lawu. Jurnal Bahan Alam Indonesia. 2012; 8(2):132-6.

9. Indrayanto I, Diding HP, Sarsono. Ekstrak etanol propolis menurunkan high-mobility group box 1 mencit model infertilitas jantan. Jurnal Bahan Alam Indonesia. 2013; 8(6):395-98.

10. Susanto A, Purwanto B, Mudigdo A, Suroto. Indonesian propolis extract attenuates unilateral ureteral obstruction induced renal damage by reducing oxidative stress and blood pressure. IJPCR. 2017;9(6):430-4.

11. Susanto A, Purwanto B, Mudigdo A, Suroto. Antihypertensive and superoxide dismutase effect of Indonesian propolis extract in kidney damage. IJCAR. 2017;6(10):6472-5.

12. Elgawish RAR, Rahman HGA, Abdelrazek HMA. Green tea extract attenuates CCl4induced hepatic injury in male hamsters via inhibition of lipid peroxidation and p53mediated apoptosis. Toxicology Reports. 2015;2:1149-56.

13. Yanguas SC, Cogliati B, Willebrords J, Maes M, Colle I, Bossche B, et al. Experimental models of liver fibrosis. Arch Toxicol. 2016; 90(5):1025-48.

14. Lin ZH, Xin YN, Dong QJ, Wang Q, Jiang XJ, Zhan SH, et al. Performance of the aspartate aminotransferase-to-platelet ratio index for the staging of hepatitis C-related fibrosis: an updated meta-analysis. Hepatology. 2011; 53(3):726-36.

15. El-Bini, Dhouib I, Lasram MM, Annabi A, Gharbi N, El-Fazaa S. A comparative study on toxicity induced by carbosulfan and malathion in Wistar rat liver and spleen. Pestic. Biochem. Pestic Biochem Physiol. 2015;124:21-8.

16. Xuan J, Chen S, Ning B, Tolleson WH, Guo L. Development of HepG2-derived cells expressing cytochrome P450s for assessing metabolism-associated drug-induced liver toxicity. Chem Biol Interact. 2016;255:6373.

17. Liang B, Xiao-Ling G, Jin J, Yong-Chun M, Zheng-Quan F. Glycyrrhizic acid inhibits apoptosis and fibrosis in carbontetrachloride-induced rat liver injury. World J Gastroenterol. 2015;21(17):5271-80.

18. Khan RA, Khan MR, Sahreen S. CCl4-induced hepatotoxicity: protective effect of rutin on p53, CYP2E1 and the antioxidative status in rat. BMC Complement Altern Med. 2012;12:178.

19. Li M, Xiu-Fang W, Juan-Juan S, Ya-Ping L, Yang N, Zhai S, Shuang-Suo D. Caffeic acid phenethyl ester inhibits liver fibrosis in rats. World J Gastroenterol. 2015;21(13):3893903. 